\title{
Photobacterium aphoticum sp. nov., isolated from coastal water
}

\author{
Teresa Lucena, María A. Ruvira, Javier Pascual, Esperanza Garay, \\ M. Carmen Macián, David R. Arahal and María J. Pujalte
}

Correspondence

María J. Pujalte

maria.j.pujalte@uv.es

\author{
Departamento de Microbiología y Ecología, Colección Española de Cultivos Tipo (CECT), \\ Universidad de Valencia, Spain
}

At the time of writing, the genus Photobacterium, of the family Vibrionaceae, contained sixteen species, most of which were isolated from seawater sampled at different depths, others having been isolated from marine animals. Defined as being facultatively anaerobic and weakly halophilic, species of the genus Photobacterium were originally thought to be mostly luminescent but more than half of the recognized species in the genus do not display this ecologically important character. Only $P$.

\footnotetext{
Abbreviations: NJ, neighbour-joining; ML, maximum-likelihood; MP, maximum-parsimony.

The GenBank/EMBL/DDBJ accession number of $16 \mathrm{~S}$ rRNA gene of strain CECT $7614^{\top}$ is FN796493. Accession numbers of newly reported gyrB and recA gene sequences of Photobacterium aphoticum CECT $7614^{\top}$, Photobacterium angustum CECT $5690^{\top}$, Photobacterium halotolerans CECT $5860^{\top}$, Photobacterium ganghwense CECT $7641^{\top}$ and Photobacterium rosenbergii CECT $7644^{\top}$ are FN796483-FN796487 and FN796488-FN796492, respectively.
}

Three supplementary figures and one supplementary table are available with the online version of this paper. phosphoreum, the type species of the genus, $P$. leiognathi, $P$. aquimaris, $P$. kishitanii and $P$. ganghwense have been described as being luminescent. Some of the luminescent species are symbionts of deep-sea fishes that hold them in specialized luminous organs (Ast \& Dunlap, 2005; Dunlap \& Ast, 2005), while other species, such as $P$. damselae, are pathogenic for marine animals. Phylogenetic positions of other members of the family Vibrionaceae showed members of the genus Photobacterium grouping with members of the genus Aliivibrio, whose earliest named species, A. fischerii and A. logei were once classified as species of the genus Photobacterium. Members of the recently described genera Grimontia and Enterovibrio also group with $P$. damselae in some phylogenetic analyses using $16 \mathrm{~S}$ rRNA gene sequences. Intrageneric relationships present between members of the genus Photobacterium usually mean that they are distributed into three clades (Jung et al., 2007; Park et al., 2006; Rivas et al., 2006; Yoshizawa et al., 2009); the first containing $P$. phosphoreum along with $P$. iliopiscarium, $P$. angustum, $P$. aquimaris and 
P. kishitanii; the second containing P. profundum together with other psychrophilic species isolated mostly from deep waters, including $P$. indicum, $P$. frigidiphilum, $P$. aplysiae and $P$. lipolyticum; and a third containing $P$. ganghwense, $P$. rosenbergii, $P$. halotolerans and $P$. lutimaris. The species $P$. damselae and $P$. leiognathi show an unstable association with the $P$. phosphoreum group. During the writing of this manuscript, two new species of the genus Photobacterium, P. gaetbulicola (Kim et al., 2010) and P. jeanii (Chimetto et al., 2010), were described and as such were included in the analyses. Strain $\mathrm{M} 46^{\mathrm{T}}$, isolated from coastal seawater of the Western Mediterranean Sea, was characterized and found to be a new member of the genus Photobacterium and grouped with the third intrageneric cluster, showing the highest $16 \mathrm{~S}$ rRNA sequence similarity to $P$. rosenbergii $(96.8 \%)$.

Strain $\mathrm{M} 46^{\mathrm{T}}$ was isolated from surface seawater collected at

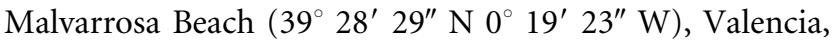
Spain, in July 2008 . Seawater $\left(25^{\circ} \mathrm{C}\right.$; pH 8) was plated directly on marine agar (MA) and incubated at $26{ }^{\circ} \mathrm{C}$ for 4 days, after which isolated colonies were randomly selected and restreaked on the same medium until pure cultures were obtained. Isolates were maintained as cell suspensions in marine broth (MB) supplemented with $20 \%(\mathrm{v} / \mathrm{v})$ glycerol at $-80{ }^{\circ} \mathrm{C}$. Strain $\mathrm{M}^{4} 6^{\mathrm{T}}$ was routinely grown on $\mathrm{MA}$ and $\mathrm{MB}$ at $28{ }^{\circ} \mathrm{C}$ and all media used for phenotypic characterization were supplemented with halfstrength artificial seawater (ASW; $400 \mathrm{mM} \mathrm{NaCl}, 100 \mathrm{mM}$ $\mathrm{MgSO}_{4} \cdot 7 \mathrm{H}_{2} \mathrm{O}, 20 \mathrm{mM} \mathrm{KCl}, 20 \mathrm{mM} \mathrm{CaCl} 2 \cdot 2 \mathrm{H}_{2} \mathrm{O}$ ) or marine cations supplement (MCS; Farmer \& HickmanBrenner, 2006). For some tests, luminous medium (LM), comprising $5 \mathrm{~g}$ yeast extract, $5 \mathrm{~g}$ tryptone, $1 \mathrm{~g} \mathrm{CaCO}_{3}, 20 \mathrm{~g}$ agar, $3 \mathrm{~g}$ glycerol and 11 basal medium (BM; $50 \mathrm{mM}$ Tris/ $\mathrm{HCl}, \mathrm{pH} 7.5$; Baumann \& Baumann, 1981), was used. Phenotypic characteristics of the novel strain were tested following previously described methods (Macián et al., 2001) for microscopic observation of cells and for determining colony characteristics on MA and thiosulfate-citrate-bile-sucrose (TCBS) agar, luminescence on MA and LM, oxidase and catalase activities, nitrate reduction, fermentation of D-glucose, D-galactose, sucrose, amygdalin, L-arabinose and melibiose in oxidativefermentative $(\mathrm{OF})$ medium, activities of arginine dihydrolase $(\mathrm{ADH})$ and lysine and ornithine decarboxylases (LDC, ODC) in Moeller's medium, indole production (in MB), gas production from glucose, Voges-Proskauer reaction, temperature range for growth $\left(4,15,28,37\right.$ and $\left.40{ }^{\circ} \mathrm{C}\right)$, hydrolysis of gelatin, casein, starch, alginate, Tween- 80 and DNA and the use of 26 carbohydrates, 12 organic acids and 16 amino acids and amines on BM Agar. Ionic requirements and growth in a range of salinities were determined as described by Macián et al. (2005). In addition to classical techniques of characterization based on phenotypic traits, tests in the API ZYM, API $20 \mathrm{E}$, API 50 CHE systems and in Biolog GN microplates were performed in duplicate incubating at $28{ }^{\circ} \mathrm{C}$ and using half-strength ASW or MCS as an ionic supplement in cell suspensions used as inocula.
Type strains $P$. ganghwense CECT $7641^{\mathrm{T}}, P$. halotolerans CECT $5860^{\mathrm{T}}$ and $P$. rosenbergii CECT $7644^{\mathrm{T}}$ were included in the phenotypic characterization study for comparison using miniaturized tests.

Cellular fatty acid analysis was performed at the CECT. Strains $\mathrm{M} 46^{\mathrm{T}}$, P. ganghwense CECT $7641^{\mathrm{T}}$, P. halotolerans CECT $5860^{\mathrm{T}}$ and $P$. rosenbergii CECT $7644^{\mathrm{T}}$ were cultured on MA and incubated at $28{ }^{\circ} \mathrm{C}$ for $24 \mathrm{~h}$ and fatty acid methyl esters were extracted and prepared according to standard protocols of the MIDI Microbial Identification System (Sasser, 1990). Cellular fatty acids were analysed by GC using an Agilent 6850 chromatograph with the MIDI Microbial Identification System and the TSBA6 method (MIDI, 2008) and identified using the Microbial Identification Sherlock software package. Among other differences, four fatty acids, anteiso- $\mathrm{C}_{15: 0}$, anteiso- $\mathrm{C}_{17: 0}$, iso- $\mathrm{C}_{15: 1} \mathrm{~F}$ and $\mathrm{C}_{15: 1} \omega 8 c$, were present as minor components in strain $\mathrm{M} 46^{\mathrm{T}}$ but were absent (or present in trace amounts) in the other species used for comparison (Table 1).

Differential characteristics from the phenotypic characterization of strain $\mathrm{M} 46^{\mathrm{T}}$ and other phylogenetically related species of the genus Photobacterium are given in the species description and Table 2. Colonies growing on MA or on LM agar were beige with entire edges and produced a diffusible brown pigment that was visible on the first streak after $24 \mathrm{~h}$ of incubation and extended to the entire culture after $48 \mathrm{~h}$. Growth on LM agar was more opaque and the pigment was darker than on MA. Using the same media, $P$. ganghwense CECT $7641^{\mathrm{T}}$ produced a pink pigment on LM agar that was not displayed on MA. Pigment production of the four type strains used in the comparative study is shown in Supplementary Fig. S1, available in IJSEM Online. Strain $\mathrm{M} 46^{\mathrm{T}}$ grew on TCBS as green colonies, thus being unable to ferment sucrose. Other carbohydrates (glucose, galactose and melibiose) were fermented in OF medium. Luminescence was not observed on either MA or LM medium after $24 \mathrm{~h}$ of incubation. Strain $\mathrm{M} 46^{\mathrm{T}}$ was shown to have growth factor requirements as it was unable to grow on $\mathrm{BM}$ agar $\left[50 \mathrm{mM}\right.$ Tris/HCl, pH 7.5; $19 \mathrm{mM} \quad \mathrm{NH}_{4} \mathrm{Cl} ; 0.33 \mathrm{mM}$ $\mathrm{K}_{2} \mathrm{HPO}_{4} \cdot 3 \mathrm{H}_{2} \mathrm{O} ; 0.1 \mathrm{mM} \mathrm{FeSO}_{4} .7 \mathrm{H}_{2} \mathrm{O} ; 1.3 \%$ (w/v) purified agar (Oxoid) in half-strength ASW; Baumann \& Baumann, 1981] with any of the carbohydrates, organic acids or amino acids tested as carbon sources, but grew easily on BM agar with $5 \mathrm{~g} \mathrm{l}^{-1}$ yeast extract. Strain M46 ${ }^{\mathrm{T}}$ was mesophilic and slightly halophilic and its extracellular hydrolytic abilities were limited to DNase activity, as is true of most species of the genus Photobacterium.

The results of tests on strain M46 ${ }^{\mathrm{T}}$ using API 20 E, API 50 CHE, API ZYM and Biolog GN microplate systems are reported in the species description. Strain $\mathrm{M} 6^{\mathrm{T}}$ was unable to oxidize most of the substrates in Biolog GN microplates, which was in sharp contrast to closely related species which were able to metabolize a large number of substrates (Supplementary Table S1).

The 16S rRNA gene sequence of strain $\mathrm{M} 46^{\mathrm{T}}$ and the recA and gyrB gene sequences of strains $\mathrm{M} 46^{\mathrm{T}}, P$. angustum 
Table 1. Cellular fatty acid compositions of strain $M 46^{\top}$ and closely related members of the genus Photobacterium

Taxa: 1 , strain $\mathrm{M}^{4} 6^{\mathrm{T}} ; 2$, P. halotolerans $\mathrm{CECT} 5860^{\mathrm{T}} ; 3$, P. ganghwense CECT $7641^{\mathrm{T}}$; 4, P. rosenbergii CECT $7644^{\mathrm{T}} ; 5$, P. lutimaris KCTC $12723^{\mathrm{T}} ; 6$, P. jeanii LMG $25436^{\mathrm{T}} ; 7$, P. gaetbulicola KCTC $22804^{\mathrm{T}}$. Values are the mean percentages of at least three replicas. All data from this study except for 5 (data from Jung et al., 2007), 6 (Chimetto et al., 2010) and 7 (Kim et al., 2010). -, Not detected; tr, trace amount $(<1 \%)$.

\begin{tabular}{|c|c|c|c|c|c|c|c|}
\hline Fatty acid & 1 & 2 & 3 & 4 & 5 & 6 & 7 \\
\hline \multicolumn{8}{|l|}{ Hydroxy } \\
\hline $\mathrm{C}_{11: 0} 2-\mathrm{OH}$ & - & - & - & - & - & - & 2.8 \\
\hline $\mathrm{C}_{12: 0} 3-\mathrm{OH}$ & 2.5 & 6.8 & 3.9 & 3.2 & 2.6 & 3.2 & 2.8 \\
\hline iso- $\mathrm{C}_{15: 0} 3-\mathrm{OH}$ & 1.0 & $\operatorname{tr}$ & $\operatorname{tr}$ & 1.1 & - & - & - \\
\hline \multicolumn{8}{|l|}{ Saturated } \\
\hline $\mathrm{C}_{12: 0}$ & 2.3 & 5.6 & 4.5 & 2.6 & 2.4 & 3.2 & 1.7 \\
\hline iso- $\mathrm{C}_{13: 0}$ & 1.8 & $\operatorname{tr}$ & $\operatorname{tr}$ & 1.2 & - & - & - \\
\hline $\mathrm{C}_{14: 0}$ & 3.3 & 1.0 & 4.2 & 2.6 & 2.4 & 4.0 & 4.2 \\
\hline iso- $\mathrm{C}_{15: 0}$ & 2.6 & $\operatorname{tr}$ & $\operatorname{tr}$ & 3.0 & 5.0 & 1.0 & 6.9 \\
\hline anteiso- $\mathrm{C}_{15: 0}$ & 1.5 & - & - & $\operatorname{tr}$ & - & - & - \\
\hline $\mathrm{C}_{15: 0}$ & - & - & - & - & 2.1 & - & 2.9 \\
\hline iso- $\mathrm{C}_{16: 0}$ & 1.7 & 1.9 & $\operatorname{tr}$ & 1.3 & - & 2.7 & $\operatorname{tr}$ \\
\hline$C_{16: 0}$ & 10.1 & 16.5 & 14.7 & 10.4 & 13.1 & 20.7 & 14.0 \\
\hline iso- $\mathrm{C}_{17: 0}$ & 1.5 & $\operatorname{tr}$ & $\operatorname{tr}$ & 3.8 & 1.8 & - & 3.5 \\
\hline anteiso- $\mathrm{C}_{17: 0}$ & 2.4 & $\operatorname{tr}$ & - & $\operatorname{tr}$ & - & - & - \\
\hline $\mathrm{C}_{17: 0}$ & 1.1 & 2.7 & 1.2 & 1.5 & - & - & 1.0 \\
\hline \multicolumn{8}{|l|}{ Unsaturated } \\
\hline iso- $\mathrm{C}_{15: 1} \mathrm{~F}$ & 1.6 & - & - & $\operatorname{tr}$ & - & - & - \\
\hline $\mathrm{C}_{15: 1} \omega 8 c$ & 2.5 & $\operatorname{tr}$ & $\operatorname{tr}$ & $\operatorname{tr}$ & - & - & - \\
\hline $\mathrm{C}_{16: 1} \omega 7 c$ alcohol & - & - & $\operatorname{tr}$ & - & 1.2 & - & $\operatorname{tr}$ \\
\hline $\mathrm{C}_{17: 1} \omega 8 c$ & 1.4 & 2.8 & $\operatorname{tr}$ & 1.3 & - & - & $\operatorname{tr}$ \\
\hline \multicolumn{8}{|l|}{ Summed features ${ }^{*}$} \\
\hline 1 & 1.1 & 1.0 & $\operatorname{tr}$ & $\operatorname{tr}$ & - & - & - \\
\hline 2 & 3.2 & 4.9 & 5.0 & 3.6 & 3.0 & 3.0 & 3.7 \\
\hline 3 & 37.2 & 31.6 & 38.3 & 38.0 & 43.0 & 41.1 & 33.6 \\
\hline 8 & 13.4 & 18.2 & 20.5 & 19.7 & 13.0 & - & $13.4 \dagger$ \\
\hline 9 & 2.2 & - & $\operatorname{tr}$ & 1.3 & $1.8 \dagger$ & - & $1.4 \dagger$ \\
\hline
\end{tabular}

* Summed features are groups of two or three fatty acids that cannot be separated by GLC using the MIDI system. Summed feature 1 comprises iso- $\mathrm{C}_{15: 1} \mathrm{H}$ and/or $\mathrm{C}_{13: 0} 3-\mathrm{OH}$, summed feature 2 comprises $\mathrm{C}_{14: 0} 3-\mathrm{OH}$ and/or iso- $\mathrm{C}_{16: 1} \mathrm{I}$, summed feature 3 comprises $\mathrm{C}_{16: 1} \omega 7 c$ and/or $\mathrm{C}_{16: 1} \omega 6 c$, summed feature 8 comprises $\mathrm{C}_{18: 1} \omega 7 c$ and/or $\mathrm{C}_{18: 1} \omega 6 c$ and summed feature 9 comprises $\mathrm{C}_{16: 0} 10$ methyl and/or iso- $\mathrm{C}_{17: 1} \omega 9 c$.

$\uparrow$ Values correspond to the sum of the proportions of each component of the summed feature when detected individually.

CECT $5690^{\mathrm{T}}$, P. halotolerans CECT $5860^{\mathrm{T}}$, P. ganghwense CECT $7641^{\mathrm{T}}$ and P. rosenbergii CECT $7644^{\mathrm{T}}$ were obtained in this study. Cell pellets of each strain were collected and DNA was extracted using a microbial DNA isolation kit (Ultra Clean; MO BIO Laboratories). Amplification and partial sequencing of $16 \mathrm{~S}$ rRNA, recA and gyrB genes were performed as described previously (Lucena et al., 2010; Pascual et al., 2010). The new sequences were compared with those available in gene databases using the NCBI BLAST
Table 2. Differential characteristics of strain $M 46^{\top}$ and closely related members of the genus Photobacterium

Taxa: 1 , Strain $\mathrm{M}^{4} 6^{\mathrm{T}} ; 2$, P. halotolerans CECT $5860^{\mathrm{T}} ; 3$, P. ganghwense CECT $7641^{\mathrm{T}} ; 4$, P. rosenbergii CECT $7644^{\mathrm{T}} ; 5$, P. lutimaris KCTC $12723^{\mathrm{T}}$; 6, P. jeanii LMG $25436^{\mathrm{T}}$ and 7, P. gaetbulicola KCTC $22804^{\mathrm{T}}$. All data from this study except for 5 (data from Jung et al., 2007), 6 (Chimetto et al., 2010) and 7 (Kim et al., 2010). +, Positive; -, negative; NA, data not available.

\begin{tabular}{|c|c|c|c|c|c|c|c|}
\hline Characteristic & 1 & 2 & 3 & 4 & 5 & 6 & 7 \\
\hline Growth at $4{ }^{\circ} \mathrm{C}$ & - & + & - & - & + & - & - \\
\hline Growth at $40{ }^{\circ} \mathrm{C}$ & - & - & + & - & + & - & + \\
\hline \multicolumn{8}{|l|}{ API 20 E tests: } \\
\hline Arginine dihydrolase & + & - & + & + & + & + & - \\
\hline Indole production & - & - & + & + & + & - & - \\
\hline Gelatinase & - & + & + & - & - & + & - \\
\hline \multicolumn{8}{|l|}{$\begin{array}{l}\text { Acid production from } \\
\text { (API } 20 \mathrm{E} \text { ): }\end{array}$} \\
\hline myo-Inositol & - & - & + & + & + & - & + \\
\hline Rhamnose & - & - & + & + & - & - & - \\
\hline Sucrose & - & + & - & + & + & - & + \\
\hline Arabinose & - & + & - & - & - & - & - \\
\hline Melibiose & + & - & - & + & - & + & + \\
\hline Mannitol & + & + & + & + & - & - & + \\
\hline \multicolumn{8}{|l|}{$\begin{array}{l}\text { Fermentation of } \\
\text { (API } 50 \text { CHE): }\end{array}$} \\
\hline D-Xylose & + & + & - & - & + & NA & NA \\
\hline Aesculin & + & - & - & + & NA & NA & NA \\
\hline Salicin & - & - & + & + & NA & $\mathrm{NA}$ & NA \\
\hline Cellobiose & - & - & - & + & + & NA & NA \\
\hline \multicolumn{8}{|l|}{$\begin{array}{l}\text { Enzymic activities } \\
\text { (API ZYM) }\end{array}$} \\
\hline Estearase lipase (C8) & - & - & + & + & + & + & + \\
\hline Cystine arylamidase & - & - & - & - & + & - & - \\
\hline \multicolumn{8}{|l|}{ Oxidization of (Biolog GN): } \\
\hline $\begin{array}{l}\text { Tweens } 40 \text { and } 80, \\
\text { maltose, D-mannitol, } \\
\text { trehalose, citric acid, } \\
\text { succinic acid, glycerol, } \\
\text { D-alanine, L-alanine, } \\
\text { L-alanyl glycine, } \\
\text { L-asparagine, } \\
\text { L-glutamic acid, } \\
\text { L-proline, L-serine, } \\
\text { inosine, thymidine }\end{array}$ & - & + & + & + & + & NA & NA \\
\hline
\end{tabular}

program (http://blast.ncbi.nlm.nih.gov/Blast.cgi). Related sequences were further analysed using the ARB program package (Ludwig et al., 2004) (http://www.wzw.tum.de/ mikrobiologie/). Automated sequence alignments were corrected manually using the ARB_EDIT sequence editor. Phylogenetic analysis using alternative treeing methods (maximum-parsimony, maximum-likelihood and distance matrix) and data subsets was performed using the appropriate ARB tools (Ludwig et al., 2004). Phylogenetic analysis of the individual and concatenated sequences of $16 \mathrm{~S}$ rRNA, recA and gyrB genes confirmed that strain $\mathrm{M} 46^{\mathrm{T}}$ belonged to the genus Photobacterium, always grouping 
closely with P. ganghwense CECT $7641^{\mathrm{T}}$ and $P$. halotolerans CECT $5860^{\mathrm{T}}$.

Sequence analysis performed with the 16S rRNA gene showed that strain $\mathrm{M} 46^{\mathrm{T}}$ had the highest sequence similarity $(96.8 \%)$ to $P$. rosenbergii CECT $7644^{\mathrm{T}}$ but showed maximum sequence similarities to $P$. ganghwense CECT $7641^{\mathrm{T}}$ when gyrB and recA gene sequences were analysed $(85.0 \%$ and $87.4 \%$, respectively).

Phylogenetic trees obtained with the neighbour-joining (NJ) algorithm and respective distance matrices based on almost complete 16S rRNA, partial recA, partial gyrB and concatenated gene sequences of strain $\mathrm{M} 46^{\mathrm{T}}$ and closely related species are shown in Fig. 1. Trees based on the 16S rRNA gene that were reconstructed using the maximum-parsimony (MP) and maximum-likelihood (ML) algorithms (Supplementary Fig. S2 and S3) did not display the same topology as that obtained when using the NJ method. In NJ analysis, the genus Photobacterium was organized into three clades. The relative branching order within each clade was almost identical between phylogenetic trees reconstructed using different gene sequences; however, the positioning of species $P$. jeanii, $P$. leiognathi and $P$. damselae subsp. damselae differed between them. The joint position of the genera Alivibrio and Vibrio (represented by the type strain of the type species of each genus) also varied between the trees, whereas other representatives of the family Vibrionaceae, Grimontia, Enterovibrio and Salinivibrio, always maintained an outgroup position. In all $\mathrm{NJ}$ trees, strain $\mathrm{M} 46^{\mathrm{T}}$ was always the sister species of $P$. halotolerans and $P$. ganghwense.

The NJ phylogenetic trees obtained using $r e c A$ and $g y r B$ gene sequences (Fig. 1) also positioned strain $\mathrm{M} 46^{\mathrm{T}}$ in the proximity of $P$. ganghwense and $P$. halotolerans. Likewise, the $\mathrm{NJ}$ tree based on the concatenated gene sequences (only species for which all three gene sequences were available were included) shows the same relative position of strain $\mathrm{M} 46^{\mathrm{T}}$ with its closest phylogenetic neighbours.

Strain $\mathrm{M} 46^{\mathrm{T}}$ showed highest $16 \mathrm{~S}$ rRNA sequence similarity with $P$. rosenbergii ( $96.8 \%$ ), which is below the value of $97 \%$ recommended by Stackebrandt \& Goebel (1994) as the threshold for the delineation of bacterial species. The classification of strain $\mathrm{M}_{4}{ }^{\mathrm{T}}$ as a novel species is also supported by the recA and $g y r B$ gene sequence analyses. Based on recA gene sequences, the maximum similarity value was $87.4 \%$ between strain $\mathrm{M} 46^{\mathrm{T}}$ and $P$. ganghwense CECT $7641^{\mathrm{T}}$, which is within the range of values seen between other species of the genus Photobacterium with validly published names $(78.3 \%$ between $P$. rosenbergii and $P$. damselae subsp. damselae and $95.5 \%$ between $P$. phosphoreum and P. illiopiscarium). Based on gyrB gene sequences the maximum similarity value was $85 \%$ between strain $\mathrm{M} 46^{\mathrm{T}}$ and $P$. ganghwense CECT $7641^{\mathrm{T}}$, which was lower than those obtained for other species pairs; $P$. kishitanii and $P$. frigidiphilum share $98 \%$ sequence similarity and 11 other species pairs share between 85 and $91 \%$ sequence similarity. These results confirm that strain $\mathrm{M} 46^{\mathrm{T}}$ represents a novel species of the genus Photobacterium.
Although no luminescence was observed, the genome of strain $\mathrm{M} 46^{\mathrm{T}}$ was tested for the presence of $l u x$ genes. Amplification and sequencing of the $\operatorname{luxA}$ gene was performed according to Wimpee et al. (1991) with the modified PCR primers luxAD (5'-CTWYTRGATCAAATGTCAAAAGGWCGT- $3^{\prime}$ ) and luxAR (5'-CTTGGTTTYGAAGCRAAYGGTTCWGA-3'). Reference strains $P$. phosphoreum CECT $4192^{\mathrm{T}}$, P. leiognathi CECT $4191^{\mathrm{T}}$, $P$. halotolerans CECT $5860^{\mathrm{T}}$ and P. ganghwense CECT $7641^{\mathrm{T}}$ were used as controls. Strain M46 ${ }^{\mathrm{T}}$ yielded a PCR product of $700 \mathrm{bp}, P$. phosphoreum CECT $4192^{\mathrm{T}}$ gave an amplicon of $750 \mathrm{bp}$ and $P$. ganghwense gave a product of $650 \mathrm{bp}$; two unspecific PCR products (500 and $1300 \mathrm{bp}$ ) were always obtained for P. leiognathi CECT $4191^{\mathrm{T}}$ and no amplicon was obtained for $P$. halotolerans CECT $5860^{\mathrm{T}}$.

PCR amplicons of $\mathrm{M} 46^{\mathrm{T}}$ and P. phosphoreum CECT $4192^{\mathrm{T}}$ were purified using an UltraClean PCR clean-up kit (MO BIO Laboratories). Subsequent sequencing reactions were done on an Abi Prism 3730 automated sequencer using a Big Dye Terminator v3.1 cycle sequencing kit in premixed format. Sequencing primers were the same ones used in the amplification reaction but diluted ten fold $(5 \mathrm{pmol})$. Further analysis with BLAST revealed that the nucleotide and the amino acid sequence of strain $\mathrm{M} 46^{\mathrm{T}}$ had no significant sequence similarity to the luxA gene of other species of the genus Photobacterium, whereas $P$. phosphoreum CECT $4192^{\mathrm{T}}$, as expected, contained the luxA gene, as previously published for this species (Wimpee et al., 1991). The deduced amino acid sequence of $\mathrm{M} 46^{\mathrm{T}}$ showed similarity to a putative acriflavin resistance protein and other membrane transporters of several species of the genera Vibrio, Alivibrio and Photobacterium. A similar result was observed in P. iliopiscarium (Ast \& Dunlap, 2005), a non-luminescent species of Photobacterium. The absence of the $\operatorname{lux} A$ gene product is consistent with the absence of luminescence for strain $\mathrm{M} 46^{\mathrm{T}}$.

Based on the phenotypic, chemotaxonomic and phylogenetic evidence presented here, strain $\mathrm{M} 46^{\mathrm{T}}$ represents a novel species of the genus Photobacterium, for which the name Photobacterium aphoticum sp. nov. is proposed.

\section{Description of Photobacterium aphoticum sp. nov.}

Photobacterium aphoticum (a.pho'ti.cum. Gr. pref. a not; Gr. n. phos, photos light; L. neut. suff. -icum suffix used with the sense of pertaining to; N.L. neut. adj. aphoticum referring to the non-luminescent character of the species).

Cells are Gram-reaction-negative, motile bacilli, 0.7$1.1 \times 2.2-3.3 \mu \mathrm{m}$. Chemo-organotrophic and facultatively anaerobic. Ferments glucose, galactose and melibiose without production of gas. Oxidase- and catalase-positive. Grows on MA, producing regular colonies $1.5-2.0 \mathrm{~mm}$ in diameter with a diffusible light-brown pigment after $24 \mathrm{~h}$ of incubation at $28{ }^{\circ} \mathrm{C}$. No luminescence was observed on MA or LM. Grows on TCBS agar producing green (sucrose-negative) colonies. Grows at 15 and $37{ }^{\circ} \mathrm{C}$ but 
(a)

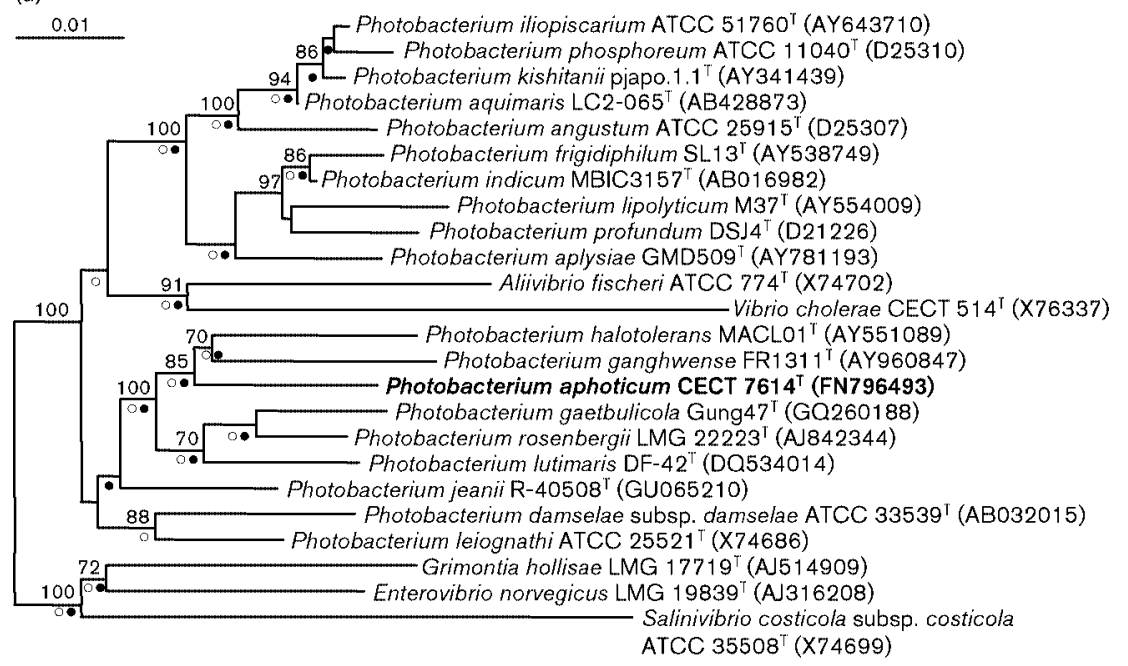

(b) Salinivibrio costicola subsp
ATCC $35508^{\top}\left(X^{7} 7699\right)$

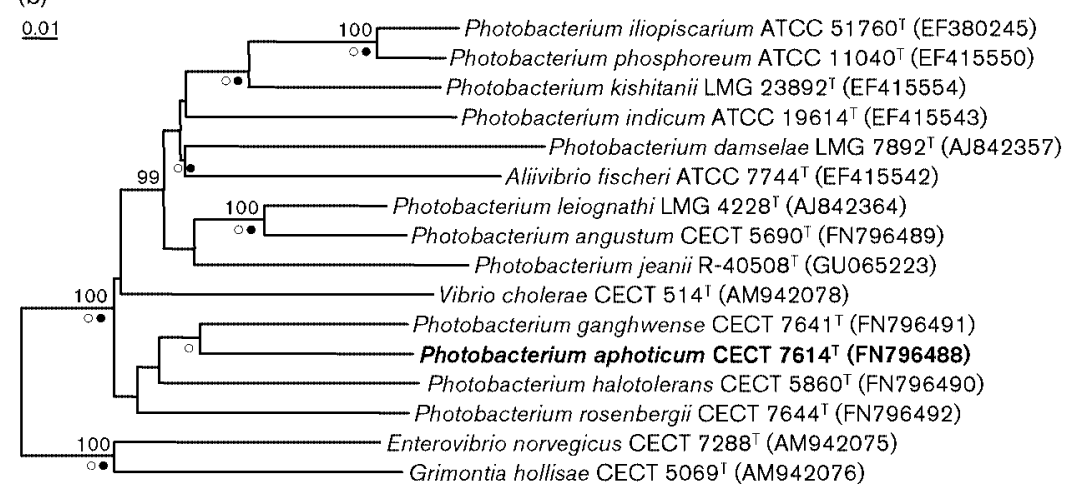

(c)

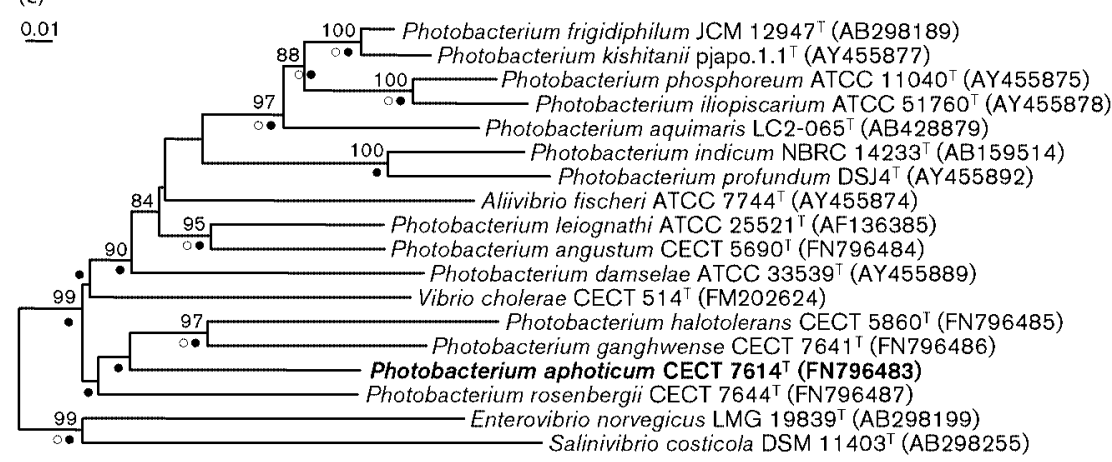

(d)

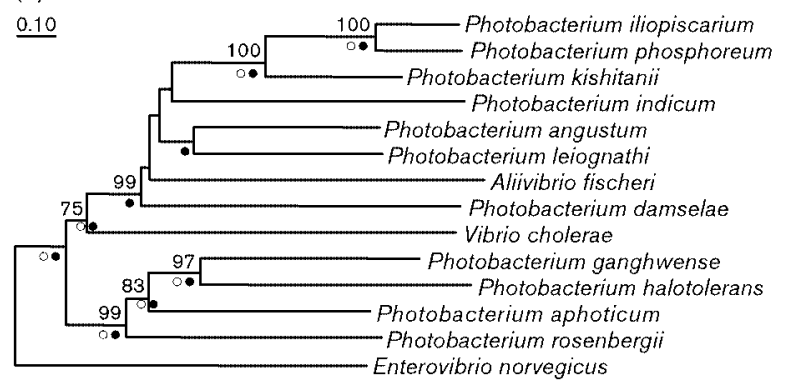

Fig. 1. Neighbour-joining phylogenetic trees based on the almost complete $16 \mathrm{~S}$ rRNA (a), partial recA (b), partial gyrB (c) and concatenated (d) gene sequences of strain $\mathrm{M} 46^{\top}$ and closely related species of the genus Photobacterium. Bootstrap values greater than $70 \%$ (based on 1000 resamplings) are shown at branch points. Nodes that were also obtained in the MP and ML trees are indicated by a circle and a filled circle, respectively. Bars represent number of substitutions per nucleotide position. 
not at 4 or $40{ }^{\circ} \mathrm{C}$. No growth is observed in the absence of $\mathrm{NaCl}$. Grows well on $0.85-7 \%$ total salts but no growth is observed at $0.35 \%$ or less or in $8 \%$ salinity or greater. Reduces nitrate to nitrite but not to $\mathrm{N}_{2}$. Positive for arginine dihydrolase (ADH) and $\beta$-galactosidase (ONPG) activities, aesculin hydrolysis and DNase activities but negative for indole production from tryptophan, urease activity, Voges-Proskauer reaction and hydrolysis of gelatin, casein, starch, alginate, agar and Tween-80. Produces acid from the following carbohydrates (API $20 \mathrm{E}$ and API 50 CHE): D-ribose, D-xylose, D-galactose, D-glucose, D-fructose, D-mannose, D-mannitol, $N$-acetyl Dglucosamine, maltose, melibiose and starch. In the API ZYM system, positive for alkaline phosphatase, leucine arylamidase, acid phosphatase, $\beta$-galactosidase and $N$-acetyl- $\beta$ glucosaminidase activities. $\alpha$-Glucosidase activity is variable. Does not assimilate any of the substrates included in the API $20 \mathrm{NE}$ system and is unable to grow on any of the carbon sources tested on BM agar, including 26 carbohydrates, 12 organic acids and 16 amino acids, suggesting a nutritional requirement that is covered by yeast extract. $N$-Acetyl-Dglucosamine, D-fructose, D-glucose and D-mannose are oxidized in Biolog GN microplates after $24 \mathrm{~h}$ incubation. Other substrates give variable responses (D-galactose and dextrin) or negative reactions. The major cellular fatty acids are $\mathrm{C}_{16: 1} \omega 7 c / \omega 6 c(37.2 \%), \mathrm{C}_{16: 0}(10.1 \%)$ and $\mathrm{C}_{18: 1} \omega 7 c l$ $\omega 6 c(13.4 \%) . \mathrm{C}_{12: 0} 3-\mathrm{OH}, \mathrm{C}_{12: 0}, \mathrm{C}_{14: 0}, \mathrm{C}_{15: 1} \omega 8 c$, iso- $\mathrm{C}_{15: 0}$, anteiso- $\mathrm{C}_{17: 0}$ and summed features $2\left(\mathrm{C}_{14: 0} 3-\mathrm{OH}\right.$ and/or iso- $\left.\mathrm{C}_{16: 1} \mathrm{I}\right)$ and $9\left(\mathrm{C}_{16: 0} 10\right.$-methyl and/or iso- $\left.\mathrm{C}_{17: 1} \omega 9 c\right)$ are also present in minor amounts $(2-4 \%)$.

The type strain, M46 ${ }^{\mathrm{T}}\left(=\right.$ CECT $7614^{\mathrm{T}}=$ KCTC $\left.23057^{\mathrm{T}}\right)$, was isolated from coastal seawater in Valencia, Spain.

\section{Acknowledgements}

This work has been supported by the Spanish Ministerio de Educación y Ciencia, project no. CGL2005-02292 to M.J.P. M.C.M. is the recipient of a contract granted by the 'support personnel' program (PTA) of the Spanish Ministry of Education and Science.

\section{References}

Ast, J. C. \& Dunlap, P. V. (2005). Phylogenetic resolution and habitat specificity of members of the Photobacterium phosphoreum species group. Environ Microbiol 7, 1641-1654.

Baumann, P. \& Baumann, L. (1981). The marine Gram-negative eubacteria: genera Photobacterium, Beneckea, Alteromonas, Pseudomonas and Alcaligenes. In The Prokaryotes, vol. 2, pp. 1302-1331. Edited by M. P. Starr, H. Stolp, H. G. Trueper, A. Balows \& H. Schleger. Berlin, Heidelberg: Springer.

Chimetto, L. A., Cleenwerck, I., Thompson, C. C., Brocchi, M., Willems, A., De Vos, P. \& Thompson, F. L. (2010). Photobacterium jeanii sp. nov., isolated from corals and zoanthids. Int J Syst Evol Microbiol 60, 2843-2848.

Dunlap, P. V. \& Ast, J. C. (2005). Genomic and phylogenetic characterization of luminous bacteria symbiotic with the deep-sea fish Chlorophthalmus albatrossis (Aulopiformes: Chlorophthalmidae). Appl Environ Microbiol 71, 930-939.

Farmer, J. J., III \& Hickman-Brenner, F. W. (2006). The genera Vibrio and Photobacterium. In The Prokaryotes, 3rd edn, pp. 508-563. Edited by M. Dworkin, S. Falkow, E. Rosenberg, K.-H. Schleifer \& E. Stackebrandt. New York: Springer.

Jung, S. Y., Jung, Y. T., Oh, T. K. \& Yoon, J. H. (2007). Photobacterium lutimaris sp. nov., isolated from a tidal flat sediment in Korea. Int $J$ Syst Evol Microbiol 57, 332-336.

Kim, Y. O., Kim, K. K., Park, S., Kang, S. J., Lee, J. H., Lee, S. J., Oh, T. K. \& Yoon, J. H. (2010). Photobacterium gaetbulicola sp. nov., a lipolytic bacterium isolated from a tidal flat sediment. Int J Syst Evol Microbiol 60, 2587-2591.

Lucena, T., Pascual, J., Garay, E., Arahal, D. R., Macián, M. C. \& Pujalte, M. J. (2010). Haliea mediterranea sp. nov., a marine gammaproteobacterium. Int J Syst Evol Microbiol 60, 1844-1848.

Ludwig, W., Strunk, O., Westram, R., Richter, L., Meier, H., Yadhukumar, Buchner, A., Lai, T., Steppi, S. \& other authors (2004). ARB: a software environment for sequence data. Nucleic Acids Res 32, 1363-1371.

Macián, M. C., Ludwig, W., Aznar, R., Grimont, P. A., Schleifer, K. H., Garay, E. \& Pujalte, M. J. (2001). Vibrio lentus sp. nov., isolated from Mediterranean oysters. Int J Syst Evol Microbiol 51, 1449-1456.

Macián, M. C., Arahal, D. R., Garay, E., Ludwig, W., Schleifer, K.-H. \& Pujalte, M. J. (2005). Thalassobacter stenotrophicus gen. nov., sp. nov., a novel marine $\alpha$-proteobacterium isolated from Mediterranean sea water. Int J Syst Evol Microbiol 55, 105-110.

MIDI (2008). Sherlock Microbial Identification System Operating Manual, version 6.1. Newark, DE: MIDI Inc.

Park, Y. D., Baik, K. S., Seong, C. N., Bae, K. S., Kim, S. \& Chun, J. (2006). Photobacterium ganghwense sp. nov., a halophilic bacterium isolated from sea water. Int J Syst Evol Microbiol 56, 745-749.

Pascual, J., Macián, M. C., Arahal, D. R., Garay, E. \& Pujalte, M. J. (2010). Multilocus sequence analysis of the central clade of the genus Vibrio by using the $16 \mathrm{~S}$ rRNA, recA, pyrH, rpoD, gyrB, rctB and toxR genes. Int J Syst Evol Microbiol 60, 154-165.

Rivas, R., Garcia-Fraile, P., Mateos, P. F., Martínez-Molina, E. \& Velázquez, E. (2006). Photobacterium halotolerans sp. nov., isolated from Lake Martel in Spain. Int J Syst Evol Microbiol 56, 1067-1071.

Sasser, M. (1990). Identification of bacteria by gas chromatography of cellular fatty acids, MIDI Technical Note 101. Newark, DE: MIDI Inc.

Stackebrandt, E. \& Goebel, J. (1994). Taxonomic note: a place for DNA-DNA reassociation and $16 \mathrm{~S}$ rRNA sequence analysis in the present species definition in bacteriology. Int J Syst Bacteriol 44, 846849.

Wimpee, C. F., Nadeau, T. L. \& Nealson, K. H. (1991). Development of species-specific hybridization probes for marine luminous bacteria by using in vitro DNA amplification. Appl Environ Microbiol 57, 1319-1324.

Yoshizawa, S., Wada, M., Kita-Tsukamoto, K., Yokota, A. \& Kogure, K. (2009). Photobacterium aquimaris sp. nov., a luminous marine bacterium isolated from seawater. Int J Syst Evol Microbiol 59, 14381442 . 